
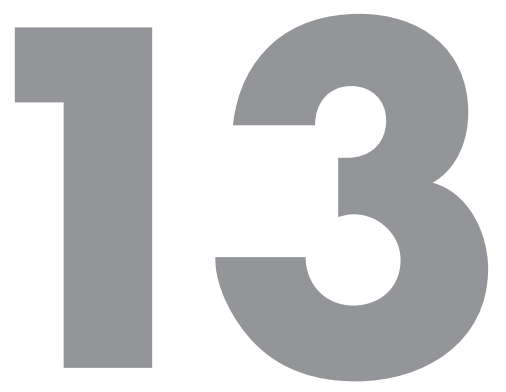

\title{
AÇÃO RESCISÓRIA DA AÇÃO RESCISÓRIA
}

A decisão de mérito transitada em julgado abre caminho para o cabimento da ação rescisória. A sentença proferida em ação rescisória não foge desse figurino.

Não importa que seja ação rescisória da ação rescisória, que, à primeira vista, assusta o jurista com viés sobre a segurança jurídica. O que está em jogo é a defesa da ordem jurídica, e sobre ela não se pode transigir. ${ }^{1}$

Assim, em tese, cabe rescisória da ação rescisória, que, sendo proposta, objetivará a desconstituição da sentença proferida na primeira ação rescisória. ${ }^{2}$

TALAMINI, Eduardo. Coisa julgada e sua revisão, p. 158.

2 O processo civil é utilizado subsidiariamente na justiça obreira. No âmbito do processo do trabalho, essa matéria é objeto da Súmula 400 do TST: "Ação rescisória de ação rescisória. Violação de lei. Indicação dos mesmos dispositivos legais apontados na rescisória primitiva. Em se tratando de rescisória de rescisória, o vício apontado deve nascer na decisão rescindenda, não se admitindo a rediscussão do acerto do julgamento da rescisória anterior. Assim, não se admite rescisória calcada no inciso V do art. 485 do CPC para discussão, por má aplicação dos mesmos dispositivos de lei, tidos por violados na rescisória anterior, bem como para arguição de questões inerentes à ação rescisória primitiva”. (ex-OJ n. 95 da SBDI-2 - inserida em 27.09.2002 e alterada DJ 16.04.2004) - Res. 137/2005, DJ 22, 23 e 24.08.2005. Corresponde ao art. 485, inciso V, do CPC/1973 o art. 966, inciso V, do CPC/2015. 
O exemplo típico recai sobre o acórdão de mérito exarado na ação rescisória que apresente um dos vícios autorizadores da rescisão, todavia não se afasta a possibilidade de rescisão de uma decisão monocrática em que, no Tribunal, o relator tenha indeferido uma petição inicial com julgamento de mérito. Em que pese seja prudente a propositura do agravo para que a questão seja apreciada pelo colegiado, o sucumbente não está obrigado a esgotar as instâncias recursais, cabendo a ação rescisória desde o trânsito em julgado da decisão de mérito. Essa hipótese ocorre quando o relator indefere, ab initio, a própria ação rescisória por decadência, decidindo, assim, o mérito e abrindo cabimento para a ação rescisória da ação rescisória.

Por fim, anote-se que não será uma repetição ou renovação da primeira ação rescisória, pois, tecnicamente o autor deverá atacar o acórdão proferido na ação rescisória. ${ }^{3} \mathrm{Na}$ segunda rescisória, o autor deverá sustentar uma das hipóteses de cabimento do art. 966 do CPC/2015 em face da decisão meritória proferida na ação rescisória, pois é esta que agora se torna a sentença rescindenda. ${ }^{4}$

3 “(...) a causa de rescindibilidade tem que ser relativa ao acórdão que julgou a ação rescisória, e não à decisão que fora objeto da rescisória. Ou melhor, o vício ou a injustiça têm que ser surgidos no acórdão que julgou a ação rescisória, até porque a decisão que fora objeto da primeira ação rescisória fora apagada no mundo jurídico". (ALVIM, Angélica Arruda (coord.) [et al.]. Comentários ao Código de Processo Civil, p. 1123).

4 "Se a ação rescisória for julgada pelo mérito, e o acórdão padecer de algum dos vícios enumerados no art. 966, do CPC, será possível ajuizar rescisória da rescisória. Um exemplo: pode ocorrer que, por um equívoco, o Tribunal reconheça a existência de decadência e julgue a rescisória extinta, com resolução de mérito. Mais tarde, se verifique que houve erro na contagem do prazo. Será possível rediscutir o acórdão proferido na primeira rescisória.” (GONÇALVES, Marcus Vinicius Rios. Direito processual civil esquematizado, p. 568). 